\title{
How can cancer screening centers improve the healthcare system of Kazakhstan?
}

\author{
Gulnara Kulkayeva1, Nurgul Azhdarova ${ }^{1}$, Bibigul Sarymsakova ${ }^{1}$, Assel Khassenova ${ }^{1}$, Gulnur Zhakhina ${ }^{2}$ \\ ${ }^{1}$ Center for Cancer Disease Control, National Research Oncology Center, Nur-Sultan, Kazakhstan \\ ${ }^{2}$ Science Department, National Research Oncology Center, Nur-Sultan, Kazakhstan
}

Received: 2021-09-02.

Accepted: 2021-11-23

This work is licensed under a Creative Commons Attribution 4.0 International License

J Clin Med Kaz 2021; 18(6):20-24

Corresponding author: Sarymsakova Bibigul.

E-mail: biba_0302@mail.ru; ORCID: $0000-0002-2059-5262$

\section{Abstract}

This review article notes the importance of timely detection of cancer and precancerous diseases by screening. The key objective is to analyze screening approaches in developed countries. Results of the study of the experience, effectiveness, and current situation in the organization of cancer screening trials in the Republic of Kazakhstan are considered. The analysis has been performed based on published data on oncology screening carried out in Kazakhstan (2008-2019) and independently collected data from the regions of the country. There is a tendency of growth of morbidity rate and decrease of mortality rate by screening localizations for the mentioned period. The percentage of detected malignant neoplasms is relatively low (from 15\% in colorectal cancer screening to $35.4 \%$ in breast cancer screening). To study foreign experience in the organization of screening studies, the available data were taken from countries with different types of health care systems, including OECD countries (USA, UK, Germany, Turkey, Korea, Canada, Finland, Sweden, Belarus). The analysis has revealed the problematic issues of screening programs and early detection of cancer that exist in our country. Considering the experience of developed countries, proposals for upgrading the organizational and methodological approach of screenings are given to improve the quality and effectiveness of early cancer diagnosis.

Key words: oncoscreening, screening program, screening center, early cancer diagnosis, malignant neoplasms

\section{Introduction}

Cancer is one of the main causes of death in the world. Thus, in 2020, almost 10 million people died of this disease [1]. Mortality from cancer can be reduced if it is detected and treated at an early stage. One of the methods of early diagnosis of malignant neoplasms is screening.

The goal of screenings is the early active detection and treatment of asymptomatic cancer. Screening programs are effective for some but not all cancers, and these programs are usually much more complex and resource-intensive than early detection programs because they require special equipment and specially trained personnel [1].

Screening should lead to a decrease in mortality from the cancer type for which it is performed. Intermediate signs of the effectiveness of the method are a decrease in the frequency of detection of advanced forms, an increase in the frequency of early forms of cancer, and an improvement in survival rate.
Early detection of malignant tumors plays an important role in reducing mortality and, in some cases when it comes to detection of precancer, morbidity from malignant tumors. Therefore, the development of new screening methods, including the detection of molecular markers of early stages of carcinogenesis, is of great importance [2].

\section{Material and methods}

The analysis was carried out based on published data on cancer screenings conducted in the Republic of Kazakhstan (statistical collections of the Kazakh Research Institute of Oncology and Radiology for 2008-2019), articles, publications, and independently collected data from the regions of the country. To study foreign experience in organizing screening studies, opensource data such an information from WHO website were taken from countries with different types of health care systems, including OECD countries (USA, Great Britain, Germany, Turkey, Korea, Canada, Finland, 
Sweden, Belarus). Inclusion criteria: by keywords, availability of statistical data; exclusion criteria: screening types other than for cancer (for example, for early detection of cardiovascular diseases, glaucoma, diabetes mellitus).

\section{Key goals of screening}

The era of modern screening dates to Wilson and Jenner's historically important publication Principles and Practices of Disease Screening, published as a monograph by the World Health Organization, which introduced the concept of screening and proposed 10 principles to guide the appropriateness of screening for health promotion [3]. The concept of health screening has spread rapidly and is now widely accepted in most developed countries.
In European Union countries, screening programs vary widely, but there are key goals to strive for. These include a single national body in the country responsible for policy and program implementation, a clear commitment to longestablished screening criteria, an accurate population register, greater universality of access in different areas of a given country, and different socioeconomic groups [3].

According to the experience of several foreign countries, risk groups, methods, and approaches vary, but all screening programs are aimed to detect certain diseases in the target groups. Moreover, many foreign countries with different types of health care systems are creating separate organizational structures to evaluate and select screening and other preventive interventions. The experience of the USA, UK, Germany, Turkey, Finland, as well as Belarus and Kazakhstan in conducting cancer screenings, is presented in Table 1 [4].

Table $1 \quad$ World experience in conducting cancer screenings

\begin{tabular}{|c|c|c|c|c|}
\hline \multirow{2}{*}{ Country } & \multicolumn{4}{|c|}{ Screening type } \\
\hline & Cervical cancer & Breast cancer & Colorectal cancer & Others \\
\hline USA & $\begin{array}{l}\text { 21-30 y.o.: every } 3 \text { years - cytology } \\
30-65 \text { y.o.: every } 3 \text { years - cytology } \\
\text { or every } 5 \text { years for HPV }\end{array}$ & $\begin{array}{l}\text { 50-74 y.o.: mammography } \\
\text { every } 2 \text { years }\end{array}$ & $\begin{array}{l}\text { 50-75 y.o.: fecal occult blood } \\
\text { test annually + colonoscopy } \\
\text { every } 10 \text { years }\end{array}$ & $\begin{array}{l}\text { Lung cancer: } 55-80 \text { y.o., low- } \\
\text { dose CT } \\
\text { Skin cancer: } 10-24 \text { y.o., } \\
\text { doctor's consultation }\end{array}$ \\
\hline UK & $\begin{array}{l}\text { 25-49 y.o.: Screening for cervical } \\
\text { cancer every } 3 \text { years } \\
\text { 50-64 y.o.: smear for cytology } \\
\text { every } 5 \text { years }\end{array}$ & $\begin{array}{l}\text { 50-71 y.o.: mammography } \\
\text { every } 3 \text { years }\end{array}$ & $\begin{array}{l}\text { 60-74 y.o.: fecal occult blood } \\
\text { test every } 2 \text { years }\end{array}$ & \\
\hline Germany & $\begin{array}{l}\text { Women over } 20 \text { y.o.: annually, } \\
\text { smear for oncocytology }\end{array}$ & $\begin{array}{l}\text { 50-70 y.o.: mammography } \\
\text { every } 2 \text { years }\end{array}$ & $\begin{array}{l}\text { From the age of } 50 \text { : analysis } \\
\text { of feces for occult blood } \\
\text { annually; } \\
\text { From } 55 \text { y.o.: + colonoscopy }\end{array}$ & $\begin{array}{l}\text { Skin cancer: over } 35 \text { y.o. (man/ } \\
\text { woman) } \\
\text { Prostate cancer: over } 45 \text { years } \\
\text { old }\end{array}$ \\
\hline Turkey* & There is a screening & $\begin{array}{l}\text { Women over } 40 \\
\text { y.o.: mammography, } \\
\text { ultrasound, mammologist } \\
\text { consultation }\end{array}$ & & \\
\hline Korea & $\begin{array}{l}20 \text { years and older (women): } \\
\text { every } 2 \text { years, smear for } \\
\text { oncocytology }\end{array}$ & $\begin{array}{l}40 \text { years and older } \\
\text { (women): every } 2 \text { years, } \\
\text { mammography }\end{array}$ & $\begin{array}{l}50 \text { years and older (man/ } \\
\text { woman): every year } \\
\text { 1. Fecal occult blood test } \\
\text { (FOBT) } \\
\text { 2. Colonoscopy (biopsy) }\end{array}$ & $\begin{array}{l}\text { Stomach cancer: } 40 \text { years and } \\
\text { older, every } 2 \text { years } \\
\text { Liver cancer: high-risk group, } \\
\text { ultrasound and AFP, every } 6 \\
\text { months. }\end{array}$ \\
\hline Canada & $\begin{array}{l}25-69 \text { y.o.: every } 3 \text { years, smear } \\
\text { for oncocytology }\end{array}$ & $\begin{array}{l}\text { 50-65 y.o.: mammography } \\
\text { every } 2 \text { or } 3 \text { years }\end{array}$ & $\begin{array}{l}50-59 \text { y.o., } 60-75 \text { y.o.: } \\
\text { fecal occult blood test, every } 2 \\
\text { years OR } \\
\text { sigmoidoscopy every } 10 \text { years }\end{array}$ & $\begin{array}{l}\text { Lung cancer: } 55-80 \text { y.o., low- } \\
\text { dose CT }\end{array}$ \\
\hline Finland* & $\begin{array}{l}\text { 25-65 y.o.: once every } 5 \text { years, } \\
\text { smear for oncocytology }\end{array}$ & $\begin{array}{l}\text { 50-69 y.o.: once every } 2 \\
\text { years, mammography }\end{array}$ & $\begin{array}{l}\text { 60-69 y.o. (man/woman): } \\
\text { experimentally, fecal occult } \\
\text { blood test }\end{array}$ & \\
\hline Sweden & $\begin{array}{l}\text { 23-50 y.o.: once every } 3 \text { years; } \\
\text { 51-60 y.o.: once every } 5 \text { years, } \\
\text { smear for oncocytology }\end{array}$ & $\begin{array}{l}40-55 \text { y.o.: every } 18 \\
\text { months; } \\
\text { 55-74 y.o.: every } 24 \\
\text { months }\end{array}$ & & \\
\hline Belarus & $\begin{array}{l}\text { 30-65 y.o.: every } 5 \text { years, smear } \\
\text { for oncocytology }\end{array}$ & $\begin{array}{l}\text { 50-70 y.o.: every } 2-3 \text { years, } \\
\text { mammography }\end{array}$ & $\begin{array}{l}\text { 50-60 y.o.: man/woman, } \\
\text { occult blood feces, } \\
\text { colonoscopy }\end{array}$ & $\begin{array}{l}\text { Prostate cancer: } 50-65 \text { y.o., } \\
\text { men, PSA (prostate-specific } \\
\text { antigen) level determination, } \\
\text { prostate biopsy }\end{array}$ \\
\hline Kazakhstan & $\begin{array}{l}\text { 30-70 y.o.: every } 4 \text { years, smear } \\
\text { for oncocytology }\end{array}$ & $\begin{array}{l}\text { 40-70 y.o.: every } 2 \text { years, } \\
\text { mammography }\end{array}$ & $\begin{array}{l}\text { 50-70 y.o., man/woman: } \\
\text { hemoccult test, colonoscopy }\end{array}$ & \\
\hline
\end{tabular}

Countries with different types of health systems have separate structures on the national and local level that focus on the assessment and selection of screening and other preventive measures. In the USA, Canada, Germany, Sweden, the Netherlands, there are state organizations on screening policy [4]. In the presence of such structures, the outcome depends on the appropriateness and effectiveness of screening programs, as well as on the interpretation of experts.
On the other hand, the experience of countries in which the adoption and implementation of screening decisions are delegated to regional and local administration shows that this type of a screening system can lead to systemic problems in health. Experts outline possible drawbacks as a larger gap in inequity and inequality, poor communication, and lack of cooperation between government and local organizations. Countries that are transitioning to a national screening system recognize many benefits in terms of their effectiveness [5]. 


\section{Screenings in Kazakhstan}

In our country, screening studies are regulated by Article 87 (Screening studies) of the Code "On the health of the people and the health care system" of July 7, 2020 [6], which allows allocating screenings as a separate event, which requires ensuring control and timely monitoring.

The types of diseases for which it is necessary to introduce the screening, as well as the rules for organizing screening, are determined by the decision of the leadership of the Ministry of Health of the Republic of Kazakhstan $(\mathrm{MOH}$ RK) based on consideration by the relevant departments of the MOH RK and the conclusions of specialized institutions. The specialized republican health organizations are responsible for the methodological guidance and analysis of preventive medical examinations of target groups of the population [7]

According to the 2019 statistics of the Cancer Service of the Republic of Kazakhstan, lung cancer (20.6\%), stomach cancer (11.9\%), and prostate cancer $(8.6 \%)$ have highest prevalence among men [8]. Among women, breast cancer is in the first place $(27.2 \%)$, followed by cervical cancer $(9.9 \%)$ and uterine body cancer $(6.5 \%)$ [8]. At the same time, 10 localizations of cancer determine $74 \%$ of mortality from all causes of malignant neoplasms in men and women.
Today, in our country, there are 3 types of cancer screening aimed at prevention and early diagnosis of breast cancer among women (BC), cervical cancer (CC), and colorectal cancer (CRC) among men and women. Screening aims to reduce the incidence of malignant neoplasms in the target group by the timely recovery of precancerous pathology and to reduce mortality in these localizations by early diagnosis [9].

Screening programs in Kazakhstan have undergone certain evolution. It started in 2008, when first cervical cancer diagnostics (smear for oncocytology) and breast cancer diagnostics (mammography) were included [8]. Colorectal cancer screening has been performed since 2011 (iFOBT-test or total colonoscopy) [10]. The stages of development of screening programs in the Republic of Kazakhstan are graphically presented in Table 2 [11].

Statistical data for 11 years of screening (2008-2019) shows a continuing increase in the incidence rate by screening localizations. According to 2019 data, since 2008, the incidence of BC has increased by $27.8 \%$, the incidence of CC has increased by $20 \%$, and the incidence of CRC has increased by $16.1 \%$ since 2011 [8]. At the same time, mortality from breast cancer during the same period decreased by $4.7 \%$, mortality from $\mathrm{CC}$ remained unchanged -4.0 per 100 thousand population, and mortality from CRC decreased by $18.4 \%$ [8].

Development of screening programs in Kazakhstan

\begin{tabular}{|c|c|c|c|c|}
\hline Screening & Year of start & Examination & Target group & Cancellation year \\
\hline $\begin{array}{l}\text { Screening for the prevention and } \\
\text { early diagnosis of cervical cancer }\end{array}$ & 2008 & Oncocytology smear & $\begin{array}{l}\text { 30-70 years old, women, } \\
\text { every } 4 \text { years }\end{array}$ & functioning \\
\hline $\begin{array}{l}\text { Screening for prevention and } \\
\text { early diagnosis of breast cancer }\end{array}$ & 2008 & Mammography & $\begin{array}{l}40-70 \text { years old, women, } \\
\text { every } 2 \text { years }\end{array}$ & functioning \\
\hline $\begin{array}{l}\text { Screening for the prevention } \\
\text { and early diagnosis of colorectal } \\
\text { cancer }\end{array}$ & 2011 & iFOBT test, total colonoscopy & $\begin{array}{l}50-70 \text { years old, men/ } \\
\text { women, every } 2 \text { years }\end{array}$ & functioning \\
\hline $\begin{array}{l}\text { Screening for the prevention and } \\
\text { early diagnosis of esophageal } \\
\text { carcinoma and gastric cancer }\end{array}$ & 2012 & $\begin{array}{l}\text { Esophagogastroduodenoscopy } \\
\text { (EGDS) }\end{array}$ & $\begin{array}{l}50-60 \text { years old, men/ } \\
\text { women, every } 2 \text { years }\end{array}$ & 2018 \\
\hline $\begin{array}{l}\text { Screening for the prevention and } \\
\text { early diagnosis of prostate cancer }\end{array}$ & 2012 & $\begin{array}{l}\text { Prostate-specific antigen (PSA) blood } \\
\text { test, transrectal ultrasound (TRUS), } \\
\text { and biopsy }\end{array}$ & $\begin{array}{l}50-66 \text { years old, men, every } \\
4 \text { years }\end{array}$ & 2018 \\
\hline $\begin{array}{l}\text { Screening for the prevention and } \\
\text { early diagnosis of hepatocellular } \\
\text { carcinoma }\end{array}$ & 2012 & $\begin{array}{l}\text { Blood for alpha-fetoprotein, } \\
\text { ultrasound, liver CT if indicated }\end{array}$ & $\begin{array}{l}\text { Persons on the "D" register } \\
\text { with cirrhosis of the liver, } \\
\text { viral and non-viral etiology }\end{array}$ & 2018 \\
\hline
\end{tabular}

\section{Issues in cancer screening}

Despite ongoing screening programs, increased diagnostic capabilities, and the availability of highly effective diagnostic equipment in medical institutions, the proportion of patients with cancers detected by screening does not exceed some limits by type of screening: cervical cancer screening $-20.0 \%$, breast cancer screening $-35.4 \%$, and CRC screening $-15.0 \%$.

The screening programs functioning in the Republic of Kazakhstan are aimed at examining large groups of the population. It requires considerable investments in equipment and personnel, which increases the burden on the health care system, especially on primary health care (PHC) organizations that carry the main burden of conducting screenings.

It should be considered that, in addition to screening tests for cancer, primary health care organizations conduct screenings for early detection of glaucoma, diabetes mellitus, circulatory diseases. In addition, in recent years, psychiatry, phthisiology, and drug treatment services have been delegated to the PHC level.
We believe that the route, which begins with identifying individuals who meet the criteria for selection into the target group, conducting the screening itself, and reporting the results of the program is an overwhelming task for quality screening studies in PHC.

The oncologic screening programs conducted have shown the following problems: low share of cancers detected during screening, lack of a single coordinating body controlling all screenings, overburdening of primary care organizations, which affect the quality of screening examinations. In addition, their quality, of course, depends on the level of qualification of specialists conducting screening examinations and the availability of necessary equipment. Thus, according to our analysis of the data on the current state of the domestic endoscopic service, there are also systemic drawbacks and unresolved problems in the organization of the service such as the lack of the necessary regulatory framework, insufficient provision of endoscopists and other equipment, low detectability of CRC. Consequently, there is no appropriate level of availability and quality of CRC screening. 
In addition, in Kazakhstan, the main attention is paid to the conduct of the screening examinations themselves, and not enough work is being done in the direction of scientific and methodological support of screening programs [7].

\section{Proposals for improving organizational approaches to screening}

In order to improve the conduct of screenings, we propose to change the organizational approaches to screenings:

(1) According to the experience of some OECD countries (Belgium, Finland, Turkey), create screening centers, where the responsibility for coordinating screening lies with certified screening centers. At the same time, screening centers are responsible for providing information to the target group, sending out invitations, repeating tests, if necessary, collecting data, and transferring them to the treating physician. It is also necessary to develop uniform requirements for screening centers, which would expand the range of organizations to participate in screening, including the private sector. The screening algorithm for organizing screening centers is shown in Figure 1.

Figure 1 - Algorithm for organizing screenings centers

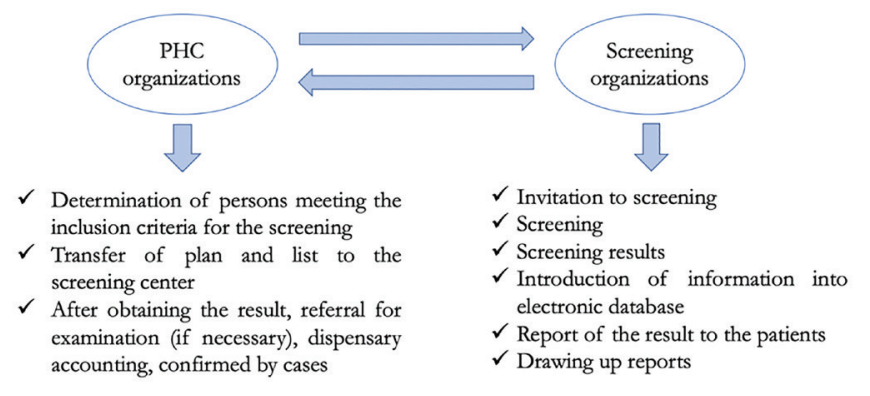

The establishment of screening centers would provide an opportunity for better screening in the country and would relieve the burden on PHC organizations. In addition, screening centers could conduct outreach work and draw the attention of both the population and employers to timely screenings.

(2) Strengthen the coordinating role of the branch state body in evaluating, controlling, and monitoring the screening programs conducted. Strategic leadership and accountability are key components to achieve screening program effectiveness and cost-effectiveness. They must be present at all levels of screening service delivery. From the outset of implementation, a team should be in place to guide the work of the program at the national or regional levels.

In this regard, we propose to create a permanent coordinating council on screening studies under the Ministry of Health, which will control and monitor all types of screenings carried out in the Republic of Kazakhstan, be an important central point of reference, when considering all issues related to screening studies, as well as allowing to influence the evaluation of the effectiveness of national screening programs and to determine areas for further research.

(3) Improving human resources capacity. The quality of screening depends largely on the skills of those, who perform it. All personnel needed for screening should be well trained. It should be noted that every year the list of health care organizations providing primary health care, which have been delegated the authority to conduct screening tests, is expanding and their training should be intensified.

4) Expanding the list of screenings and changing methodological approaches, taking into account the morbidity structure of malignant neoplasms. We believe that today the specific weight of malignant neoplasms of the digestive system takes the first place and it is urgent for Kazakhstan.

Therefore, we consider it expedient to work out the issue of renewal of screening investigations for early diagnostics of esophageal and stomach cancer.

(5) We suggest working on the issue of improving existing screening programs (cervical and colorectal screening) and introducing new types of screenings, such as lung cancer screening.

Lung cancer is the deadliest cancer. In Kazakhstan, lung cancer invariably occupies the leading place regarding the mortality rate. Cancer symptoms appear mostly at a late stage when treatment is much less effective. Screening would allow cancer to be detected much earlier. The earlier cancer is detected, the more effective its treatment is, improving outcomes for people with the disease and reducing treatment costs.

Low dose computed tomography (LDCT) is the most effective screening for detecting lung cancer at an early stage [12], and it would also enable the use of artificial intelligence in making the diagnosis.

The largest study to date on lung cancer screening was conducted in Belgium and the Netherlands (results published in 2020). It was found that the number of deaths from lung cancer dropped by $24 \%, 10$ years after LDCT was offered to people at high risk of developing the disease [12].

6) to develop scientifically grounded recommendations on screening for the Ministry of Health of the Republic of Kazakhstan, it is recommended to appoint a responsible organization that will function to organize work on the development of scientifically grounded recommendations for screening. The organization could use the algorithm of the work of the independent UK National Screening Committee (UK NSC) as an example.

Among the screening organizations of all European countries, the UK NSC is recognized as a best practice for organizing screening. Therefore, it is necessary to study the experience of UK to improve screening processes in the health care system of Kazakhstan. The UK NSC approach ensures uniformity of access, broad adherence to screening principles, and transparent decision-making and quality assurance processes, thereby optimizing the potential for screening to gain more than harm, given the resources available [5].

\section{Conclusion}

The introduction of screening studies in the Republic of Kazakhstan is a significant contribution to the measures of early diagnosis of cancer and precancerous conditions. Although the existing clinical protocols show success, there is a need for more in-depth consideration of issues of screening effectiveness, increased attention to the assessment of the screening process. It is necessary to change the methodology, and conduct screening studies, based on the recommendations of the World Health Organization and the best foreign experience. It is also important to involve the population in the decision-making processes of screening and provide them with clear and understandable information about its consequences.

Disclosures: There is no conflict of interest for all authors.

Acknowledgements: None.

Funding: None. 


\section{References}

1. World Health Organization. Cancer. Published March 3, 2021. Accessed August 2, 2021. URL: https://www.who.int/ru/news-room/factsheets/detail/cancer

2. Starinsky VV, Garin AM, Davydov MI, Kaprin AD, Licinitser MR, Moiseenko VM, et al. Early detection of malignant tumors - screening. ONCOLOGY.ru (periodic scientific and practical, peer-reviewed and electronic publication). Viewed August 10, 2021. URL: http://www. oncology.ru/specialist/diagnostic/screening/procurement_performance_of_screening/.

3. Holland WW, Stewart S, Masseria C. Policy Foundations. Screening in Europe. European Observatory on Health Systems and Policies. $2008 ; 1-72$

4. Dombrowski VS, Khachatryan GR. Comparison of recommended screening programs in the United States, Canada, the Netherlands, and Germany. Pharmacoeconomics. Modern pharmacoeconomics and pharmacoepidemiology. 2016;9(4):46-53. https://doi. org/10.17749/2070-4909.2016.9.4.046-053

5. Health Council of Canada(2013). A scoping review of screening in Canada. URL: https://macsphere.mcmaster.ca/bitstream/11375/14854/1/ fulltext.pdf Accessed August 13, 2021.

6. Ministry of Health of the Republic of Kazakhstan. The health of the People and Health System Code of July 7, 2020, No. 360-VI ZRC, Art. 87.

7. Salidat Kairbekova National Research center for Health Development. "What should be the rational decision-making process for screening programs?" Policy brief. URL: http://www.rcrz.kz/index.php/ru/2017-03-12-10-51-14/analiticheskaya-spravka-policy-brief. Accessed August 24, 2021.

8. Kaidarova DR, Baltabekov NT, Dushimova ZD, Shatkovskaya OV, Seisenbaeva GT, Azhmagambetova AE, Zhylkaidarova AJ, Lavrentieva IK. Indicators of oncological service of the Republic of Kazakhstan for 2019. KazIOR, Almaty 2020; 1-225

9. Ministry of Health of the Republic of Kazakhstan. On approval of target groups of persons subject to screening studies, as well as rules, volume, and periodicity of these studies of October 30, 2020.

10. Republican Center for Health Development of the Republic of Kazakhstan. Analytical report on problematic issues in the organization of screening in Kazakhstan. URL: http://www.rcrz.kz/100/p94-1.pdf Accessed August 20, 2021.

11. Suleimenov M. A program for early diagnosis of four types of cancer has been launched in Kazakhstan. URL: https://online.zakon.kz/ Document/?doc_id=31321887\#pos=3;-52 Accessed August 21, 2021.

12. Janette R, Georgia H, Nikolaos I.K. Lung cancer screening. European Lung Foundation, European Respiratory Society. 2021. URL: https://europeanlung.org/wp-content/uploads/2021/04/Lung-Cancer-Screening-Factsheet_RU.pdf 